\title{
Characteristics of Islamic Financial Literacy based on Demographic and Religiosity
}

\author{
$1^{\text {st }}$ Djubaedi Yunus ${ }^{1}, 2^{\text {nd }}$ Ahmad Rodoni ${ }^{2}, 3^{\text {rd }}$ Riris Aishah Prasetyowati ${ }^{3}, 4^{\text {th }}$ Amin Suma ${ }^{4}$, \\ $5^{\text {th }}$ AM. Hasan $\mathrm{Ali}^{5}, 6^{\text {th }}$ Umar Al-Haddad ${ }^{6}$ \\ \{ydjubaedi@gmail.com ${ }^{1}$, ahmad.rodoni@uinjkt.ac.id ${ }^{2}$, riris.aishah@uinjkt.ac.id ${ }^{3}$, \\ aminsuma@uinjkt.ac.id ${ }^{4}$, hasan.ali@uinjkt.ac.id ${ }^{5}$, umar.al-haddad@uinjkt.ac.id $\left.{ }^{6}\right\}$ \\ Sy arif Hiday atullah State Islamic University of Jakarta, Indonesia ${ }^{123456}$
}

\begin{abstract}
This paper is the first part of the dissertation with the title Demographic and Religiosity Factors as well as Their Implications for Islamic Financial Literacy. The method used in this study is a quantitative method using statistical data analysis techniques Structural Equation Model - Partial Least Square (SEM-PLS). The result of this research is Islamic financial literacy characteristics of product and service knowledge, counting skills, attitudes and behavior, delivery channel, resources, and reference reflected latent variable of Islamic financial literacy and demographic characteristics of gender, age, education, and income expenditure are reflected by a latent variable of demographic, and religiosity characteristics of monotheism, rituals, muamalah, morals, and experience are reflected by a latent variable of religiosity. Accordingly, characteristics of Islamic financial literacy, demographic, and religiosity could be used by stakeholders in the Islamic financial industry to socialize the product and services globally and nationally in developing business and marketing strategies, which prioritize financial literacy and inclusion and financial education strategies according to the level developed by financial institutions.
\end{abstract}

Keywords: SEM-PLS, demographic, religiosity, and Islamic financial literacy.

\section{Introduction}

Sharia and Conventional Bank assets in Indonesia are depicted in Figure 1 below, the total assets of Sharia and Conventional Banks from 2011 to 2018, in trillion rupiah. Total assets of Sharia Banks from the total assets of the Bank nationally were only $3.97 \%, 4.57 \%, 4.88 \%$, $4.84 \%, 4.86 \%, 5.3 \%, 5.74 \%$, and $5.91 \%$ respectively. Meanwhile, the total assets of Conventional Banks show 95.43\%, 95.12\%, 95.16\%, 95.14\%, 94.7, 94.26\% and 94.09\% respectively. These statistics show that the majority of Indonesian Muslims place their as sets in conventional banks. 




Fig. 1. Sharia and Conventional Bank Assets. Source: The Financial Services Authority (OJK) 2019

The results of the survey on the Is lamic financial literacy index based on regional strata are depicted in the following Figure 2 in a row from the highest order in East Java literacy index 29.4\% Muslim population 94.59\%, Aceh literacy index 21.09\% Muslim population 98.48\%, DKI Jakarta literacy index 16.4\% Muslim population $83.40 \%$. Jambi literacy index $12.73 \%$ Muslim population $98.40 \%$, North Maluku literacy index $12.73 \%$ Muslim population $75.34 \%$, West Sumatra literacy index $11.64 \%$ Muslim population $98.00 \%$, and Central Java literacy index $11.2 \%$ Muslim population $96.28 \%$.

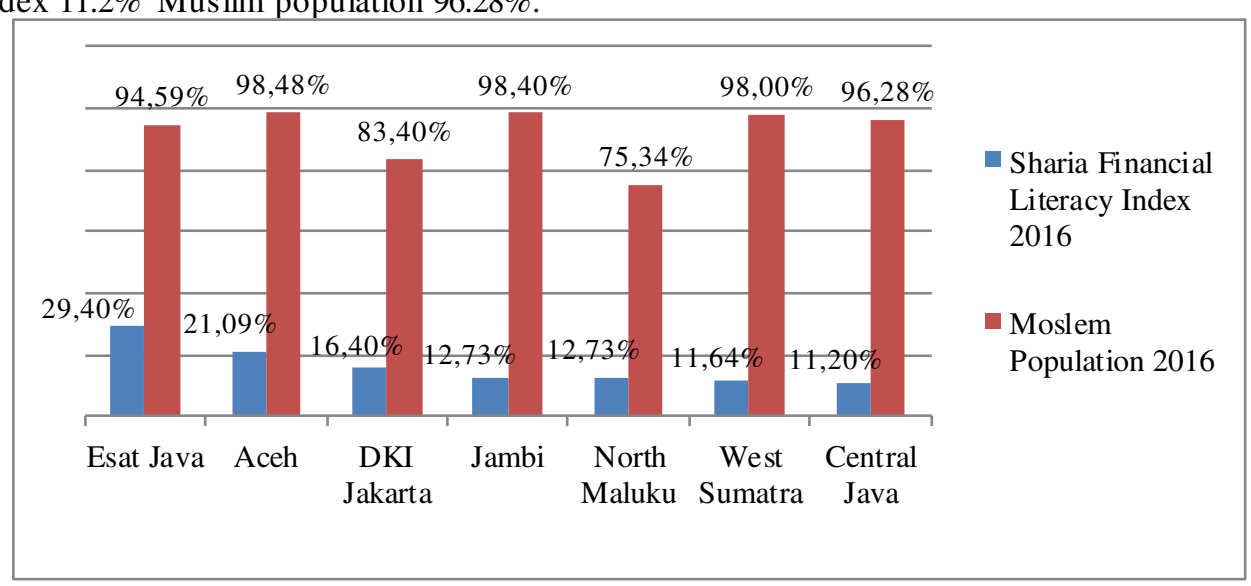

Fig. 2. Sharia Financial Literacy Index and Muslim Population By Region 2016. Source: compiled from various sources by the author

Pieter Abdullah, research director of the Center of Reform on Economics (Core) Indonesia, said that Indonesia has great potential with the largest Muslim population in the world. 
However, realizing an Islamic economy is difficult to dominate Indonesian banking. Islamic banking will grow but it is very difficult to dominate Indonesian banking. The diversity of customs and cultures and the quality of the Muslimpopulation as well as the economic system in Indonesia is a challenge in itself.

Moslem is the biggest population in Indonesia but the development of shariah financial literacy is slow compares to conventional financial literacy which can be identified as follows:

1. The low growth rate of Islamic banking assets. Until June 2018 only $6 \%$ of the total wealth of national banks, the growth rate of the market share of Islamic finance was low, only $8.5 \%$ of the entire national financial industry, and the loan growth rate was only $5.9 \%$ of the total of the national loan;

2. The national Islamic financial literacy index is much lower than the conventional financial literacy index, the difference is $8.11 \%$ compared to $29.66 \%$.

3. DKI Jakarta with a Muslim population of $83.4 \%$ and a high level of religiosity, the level of Islamic financial literacy is $16.4 \%$. Although Muslims are smaller, their financial literacy is higher than Jambi, the Muslim population is $98.4 \%$, has a financial literacy rate of $12.73 \%$, West Sumatra has a Muslim population of $98.00 \%$, has an Islamic financial literacy rate of $11.64 \%$, and Central Java a Muslim population is $96.28 \%$, an Islamic financial literacy rate is $11.20 \%$.

\section{Research methods}

Field research analyzed quantitatively with statistical methods that produce a numerical form, uses primary data from respondents' answers through questionnaires with accidental methods and qualitative research.

\subsection{Data Sources}

There are two categories of data in field research, namely primary sources and secondary sources, as follows:

\subsubsection{Primary source}

This research is the answer to a questionnaire sent to Muslim and non-Muslim communities in several cities in Indonesia sent to respondents via online social media as many as 2800 respondents. The reason the author uses social media is that it can allow interactive communication between the sender and receiver, not just for one person, and faster, besides the recipient can adjust the interaction time. The questionnaire is made using the google form application, contains statements submitted in writing made by researchers, respondents fill in or answer questionnaires made by giving a checkmark (checklist). Of the 2,800 respondents, with the Slovin formula, 400 respondents were selected, and before the research was carried out, first a research trial was conducted on 40 respondents, as the basis for the calibration of the questionnaire instrument related to the validity and reliability of the instrument.

\subsubsection{Secondary data}


Secondary data of this research comes from the literature review, including book studies, articles, journals, both hard and soft copies or online, and literature reviews related to the results of previous relevant research and other sources that are related to this research.

\subsection{Statistical Methods}

This quantitative data analysis method is the statistical technique of Structural Equation Model - Partial Least Square (SEM-PLS) with its various variations, which are simplified into a path analysis model to examine the factors that affect the level of Islamic financial literacy directly or indirectly through religiosity behavior.

This study uses 18 variables/indicators which consist of three variables but for this paper are used two variables, namely religiosity and Islamic financial literacy and 11 indicators consisting of five indicators of religiosity: monotheism, ritual, intellectual (muamalah), consequences (morals), experience (human)] and six indicators of Islamic financial literacy: knowledge of products and services, numeracy skills, attitudes and behavior, delivery channels, sources of information, reference factors. In SEM-PLS there are two relationship models, namely the inner model and the outer model, and there are intervening variables in the inner model. And this paper using the calculation results of the inner model, which will be a diagram like Figure 3 below.

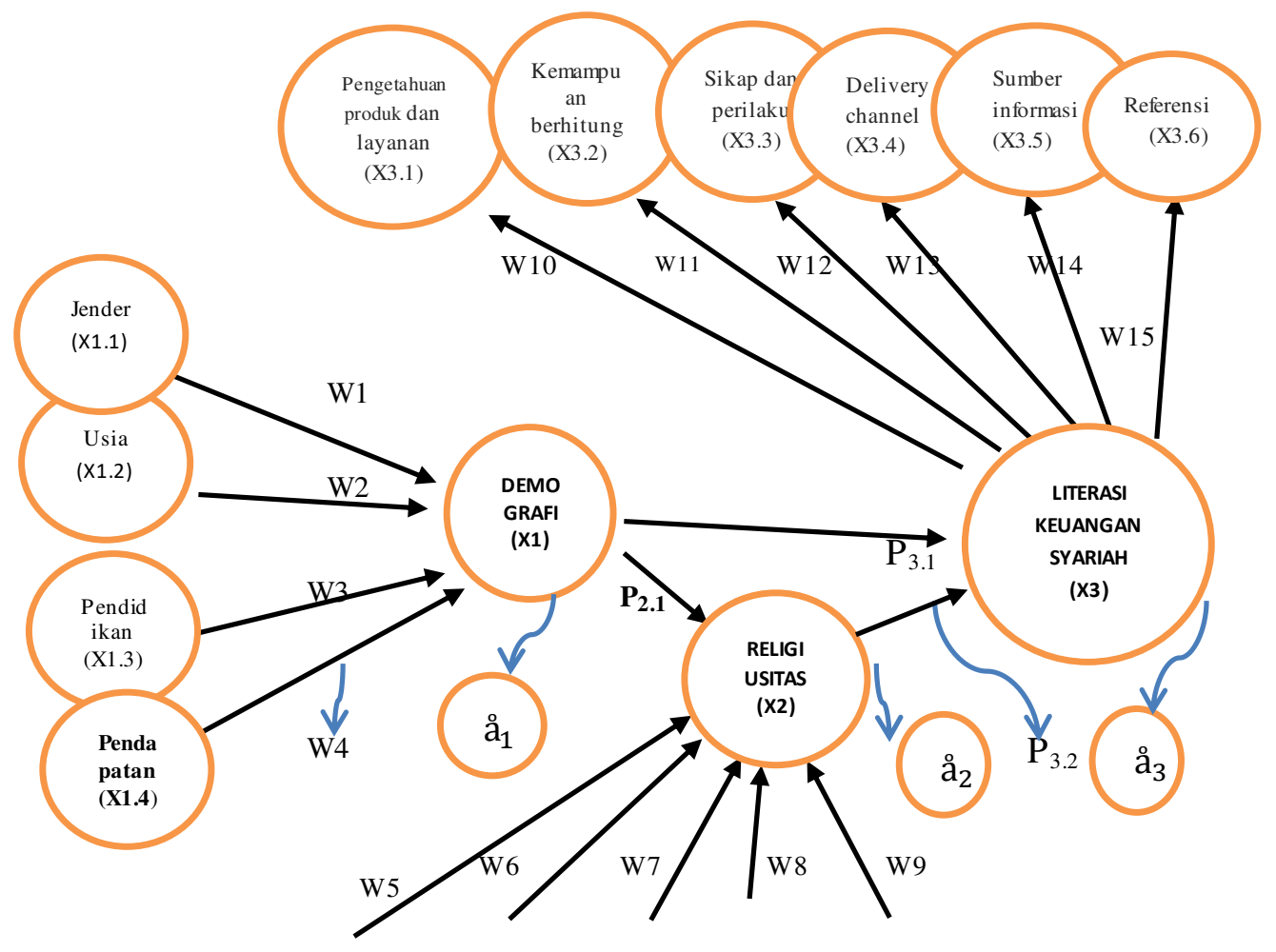




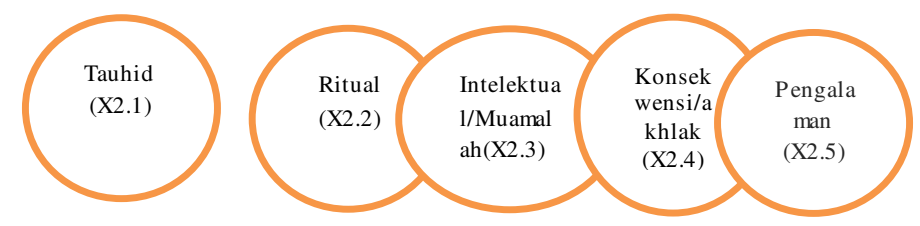

Fig. 3. Building Path Diagram of the Relationship BetweenLatent Variables in the SEM-PLS Model

\section{Literature Review:}

\subsection{Religiosity}

Most of the research on religiosity carried out by Western researchers looks from the perspective of Western society so that if it is applied to the Indonesian Muslim community, the results of the research lose the cultural relevance of religion because Western society adheres to the concept of secularism or religious privatization, will be significantly different from Muslim countries, Indonesia, for example. , nearly $88 \%$ of the population adheres to Islam, religion is recognized by Pancasila in the first precept, and is contained in the 1945 Constitution Article 29 paragraph 2. Research in Indonesia or other Muslim countries based on Islam does not cause the community to lose its cultural relevance.

Religiosity and religion cannot be separated from one another because religion is the main source of religiosity. The religion referred to here is the religion of Islam, and the main source of Islamic teachings is the Al-Qur'an and Hadith. People who are religiosity are people who behave in religiosity or who behave by Islamic teachings whose source of teachings is the AlQur'an and Hadith. Islamic financial literacy is conventional finance plus aspects of sharia. Or conventional economics is harmonized with the Qur'an and Sunnah and the opinions of scholars (inductive method). Or financial theory is derived from the Qur'an and Sunnah so that the terms financial and financial literacy (conventional) can mean Islamic financial literacy and Islamic finance, but Islamic financial literacy and Islamic finance cannot be interpreted as conventional financial literacy and conventional finance (deductive theory ). Therefore, the relationship between demography and religiosity and Islamic financial literacy is that people who are Muslims who understand Islamic finance.

The teachings contained in the Al Quran and Hadiths are related to these three variables.

Summary of sources of the Qur'an and hadith regarding demographic variables, religiosity, and Islamic financial literacy

\section{No. Al Qur'an dan Hadis}

$1 \quad$ al-'Alaq [96] : 1-5

2
al-Baqarah [2]: 284

\section{Subject}

Read, reading activities and understand what is being read

Belongs to Allah all the riches on the surface and in the heavens and the earth 


\begin{tabular}{|c|c|c|}
\hline 3 & al-Baqarah [2]: 180 & Relative ownership \\
\hline 4 & al-Baqarah [2]: 201 & Balance \\
\hline 5 & al Furqan [25]: 67 & Balance \\
\hline 6 & al-Nisa' [4]: 160-167 & Justice, zakat \\
\hline 7 & al-Anbiya' [21]: 73 & Zakat \\
\hline 8 & al-Ma'idah [5]: 120 & $\begin{array}{l}\text { Allah knows best what is hidden when humans hide } \\
\text { it }\end{array}$ \\
\hline 9 & al-Baqarah [2]: 275-280 & Usury \\
\hline 10 & al-Zukhruf [43]: 32 & Cooperation \\
\hline 11 & al-An'am [6]: 38 & Social Security \\
\hline 12 & al-Ma'idah [5]: 8 & Justice \\
\hline 13 & al-Ma'idah [5]: 12 & Zakat \\
\hline 14 & $\begin{array}{l}\text { Hadis : Book of } \\
\text { Mule jam al-Kabir Juz } \\
\text { hal. } 438\end{array}$ & $\begin{array}{l}\text { "He said: Rasulullah SAW said: Islam is built on } \\
\text { five elements, namely: testifying that there is no god } \\
\text { but Allah and Muhammad is the messenger of Allah, } \\
\text { praying, paying zakat, performing hajj and fasting } \\
\text { during the month of Ramadan. (H.R. Bukhari and } \\
\text { Muslim) }\end{array}$ \\
\hline 15 & $\begin{array}{l}\text { Hadis : Book of Bukhari } \\
\text { Waa Muslim (Mutafaq } \\
\text { Alaih),hal. } 327\end{array}$ & $\begin{array}{l}\text { From Ibn Umar RA, he said: Rasulullah SAW said: } \\
\text { Islam is built on five elements, namely: testifying } \\
\text { that there is no god but Allah and Muhammad is the } \\
\text { messenger of Allah, praying, paying zakat, } \\
\text { performing hajj and fasting in the month of } \\
\text { Ramadan. (H.R. Bukhari and Muslim) }\end{array}$ \\
\hline
\end{tabular}

Religiosity can be used as a variable in research, including in Islamic finance research. Religiosity and religion cannot be separated from one another because religion is the main source of religiosity. The religion referred to here is the religion of Islam, and the main source of Islamic teachings is the Al-Qur'an and Hadith. People who are religiosity are people who behave in religiosity or who behave by Islamic teachings whose source of teachings is the AlQur'an and Hadith. Religiosity is positioned as a potential contributor to understanding financial knowledge by expressing religious practices and beliefs. When using the religiosity variable, religion cannot be avoided from being analyzed. This is because religion is synonymous with mental health, it can reduce anxiety, provide assurance, offer hope, create self-control, use rules in an irregular world, and create self-identity. Besides, religiosity can influence other behaviors. Religiosity is one of the formers of culture Psychologically, it is the human force in compiling theoretical knowledge in the last 25 years. 


\subsubsection{Aspects of Religiosity}

The elements and factors that influence religiosity behavior are social influence, experience, needs, and thoughts.

The opinion that the concept of religiosity is a person's commitment to religiosity that can be seen through the activities and behavior of the individual concerned according to his or her religion. The indicators are as follows: First, the dimension of belief or ideology, namely one's religious dogma. For example, belief in God, angels, heaven, doomsday, and so on; Second, the ritual dimension, namely carrying out religious rituals by the demands of their religion. For example prayer, fasting, zakat, and others to show adherence to religion; Third, the dimension of religious experience or feeling that is carried out is felt by the miracles or guidance of God. For example, feeling close to God, fear God, or God saves, and so on; The four intellectual dimensions of religion by looking at religious knowledge and concepts, recognition of creation by God, efforts to increase religious knowledge, and so on; The five dimensions of the effect on religion, namely what motivates a person's behavior in social life in a society based on religion?

\subsubsection{Religiosity in context Financial Literacy}

According to Islam, humans consist of physical and spiritual elements. Both need fulfillment. Physical needs include economic activities. Spiritual needs include spiritual aspects, such as prayer, fasting, pilgrimage, and zakat

\subsection{Islamic Financial Literacy}

Until now, Islamic financial literacy does not have a definition that can be used as a working reference, even though there is an agreement among sharia experts that what is meant by Islamic financial literacy is (conventional) financial literacy, which includes components that can meet sharia requirements. The concept of Islamic financial literacy generally uses the concept of conventional financial literacy coupled with aspects of sharia. Because there is no standard concept of Islamic financial literacy, therefore academics and researchers mus t define Is lamic financial literacy.

The discussion of sharia on Islamic financial literacy contained in the sharia economic literature still uses the inductive method, which is using existing conventional economic theory and then adjusted to the Qur'an and Sunnah or with some of the opinions of scholars. The discussion uses the deductive method, the namely conventional financial theory that already exists, which departs from the sources of the Qur'an and the Sunnah.

\subsubsection{Financial Literacy Urgency}

Every day everyone makes important financial decisions. Whether a chief executive officer managing billions of dollars, a couple planning a home purchase loan, or a college student counting his lunch money. Everyday financial decisions are made. A monetary crisis occurs when bonds and credit customers have developed, in addition to credit cards or subprime bonds, alternative financial services have also developed such as daily loans, pawnshops, leasing, pension funds, and leases. The financial crisis in 2008 led to widespread changes in national policy, reduced incomes, the downfall of the government, riots made headlines, 
Kyriakidou wrote in his article. The urgency of financial literacy has become a global concern in recent years. Even in countries with developed financial markets such as the United States, only one-third answered correctly and two-thirds answered incorrectly to questions on basic concepts of money management such as interest (and compound interest), inflation, and risk diversification.

\subsubsection{Financial Literacy Theory Framework}

The financial literacy theory framework is presented in a diagram, such as a Figure 4 Financial Literacy Theory Framework. The indicator is part of the dimension and the dimension is part of the concept. Dimensions and indicators can be variables. Variables are things that can change by the elements that determine change. The theoretical framework for financial literacy that will be discussed includes definitions, dimensions, indicators, a microeconomic approach, and financial literacy education. The reasons for presenting the discussion will provide a complete picture of financial literacy to make it easier to understand the dissertation, starting with the concepts and approaches used then how to understand or financial literacy.

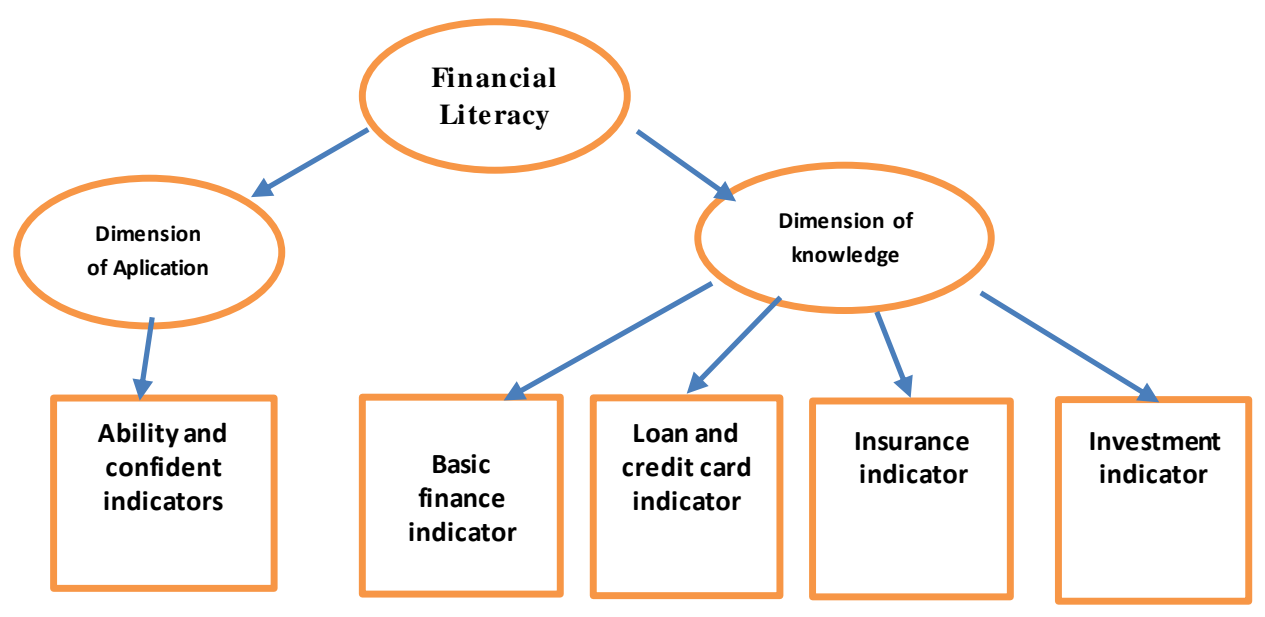

Fig. 4. Financial Literacy Theory Framework. Source: Compiled by authors from various sources

\subsubsection{Financial Literacy Dimensions}

The conceptual framework of financial literacy includes two dimensions, namely understanding (knowledge of personal finance) and applying (in transactions for financial products and services), as shown in Figure 5 below. The theoretical framework is used to measure the extent to which individuals can understand and use information related to personal finance.

There are two understandings of a person's finances, namely basic financial literacy, namely basic financial knowledge to make decisions on financial matters, and advanced financial literacy, namely understanding decisions to save and invest. The basic financial literacy theoretical framework is a). concept of arithmetic and the ability to calculate interest 
such as compound interest, b). understand inflation, c). understand risk diversification. The framework of advanced financial literacy theory is a). understand the relationship between risk and return, b). understand bonds, mutual funds, and stocks, c). understand as set pricing. There are two knowledge of investment technology, namely: a) simple technology for basic financial literacy, namely low and fixed profit rates such as bank interest, b). advanced technology for advanced financial literacy provided for customers to be able to access higher profits, depending on the level of financial knowledge.

The financial literacy dimension consists of two dimensions, namely the knowledge dimension and the application dimension. The indicators are in the dimensions of both knowledge and application together. Therefore, the knowledge dimension is discussed in succession, then the application dimension, followed by a discussion of the indicators.

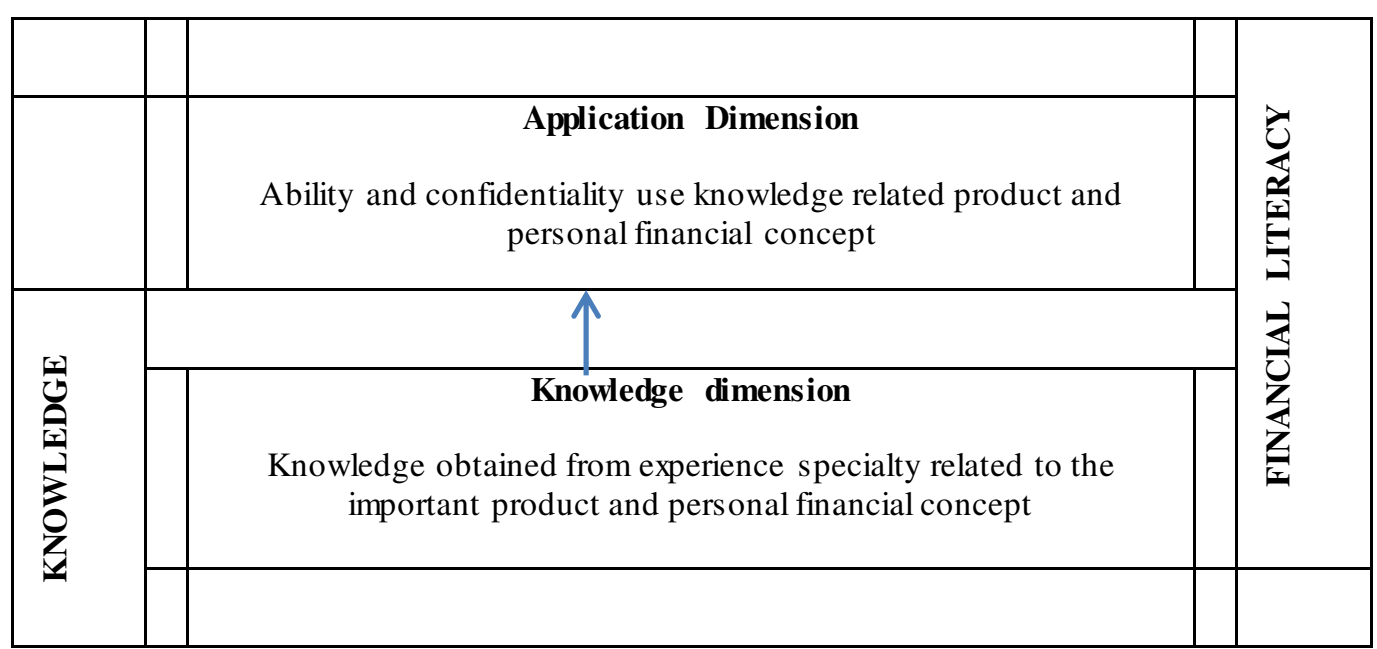

Fig.5. Financial Literacy Dimensions. Source: Sandra J. Houston, "Measuring financial literacy".

\section{Result and Discussion}

The purpose of this study was to explore whether there is an effect of demographic and religiosity variables on Islamic financial literacy in the Islamic community in Jakarta, Bogor, Depok, Tangerang, Bekasi, and several other big cities in Indonesia. The result of this study could add value to all parties who have an interest in advancing Islamic finance in Indonesia. This research product can be used as a reference in further research related to Is lamic financial literacy, whose independent variables have not been included in this study. The results of this study can be used as information for the Islamic finance industry in planning marketing strategies, education, and outreach to community groups about Islamic financial products and services.

\subsection{Descriptions of Respondents based on Demographic Characteristics}

The demographic variable questionnaire consists of nine characteristics, including gender, age, religion, place of residence, bank account, education, status, income, and employment. 
There are four demographic characteristics used for research through statistical tests, while the other five characteristics are not used in the research statistical test. Presented in two forms, first, the demographic characteristics of choice for statistical tests as indicators of demographic variables in the study, there were four genders, age, education, and income; second, demographic characteristics are not an option for statistical test indicators, namely religion, place of residence, bank account, status, and occupation.

Characteristics of respondents who become indicators of exogenous demographic variables visually through processing using $\mathrm{R}$ software are presented in a successive pie chart as follows:

\subsubsection{Gender Characteristics of Respondents}

Gender in this study has a nominal scale for women and men which can be expressed in a classification with a notation of 0 (zero) for the female and 1 (one) gender groups. Based on the results of grouping male and female gender through calculations using MS Excel software, obtained 160 female respondents and 240 male respondents. Furthermore, it is presented in a circle diagram of the visualization results using $\mathrm{R}$ software which is presented in Table 4.4 for gender frequencies as follows:

\begin{tabular}{|c|c|}
\hline \multicolumn{2}{|c|}{ Table 4.4} \\
Frequency of Gender Respondent Gender \\
\hline Gender & $\begin{array}{c}\text { Frequency } \\
\text { (Respondent) }\end{array}$ \\
\hline Woman & 160 \\
\hline Man & 240 \\
\hline total & 400 \\
\hline
\end{tabular}

\subsubsection{Characteristics of Respondents Age}

The age in this study is classified into the young age group from less than 17 years to 35 years with the notation 0 (zero) and the old from 36 years and above notation 1 (one). Based on the results of age grouping through calculations using MS Excel software. There were 26 respondents with the age classification 17 years to 25 years, 93 people 25 to 35 years, 67 people 35 years to 45 years, 85 years to 55 years 45 years, 55 years to 65 years as many as 106 and $>65$ years as many as 23 people. Furthermore, it is presented using Excell software which is presented in Table 4.5 for gender frequency in-person units as follows:

\begin{tabular}{|c|c|c|}
\hline \multicolumn{3}{|c|}{ Table 4.5} \\
\multicolumn{3}{|c|}{ Frequency of Respondent Age Clas sification } \\
\hline Classification of age & Frequency (Respondent) \\
\hline A & $17-25$ year & 26 \\
\hline B & $25-35$ year & 93 \\
\hline C & $35-45$ year & 67 \\
\hline D & $45-55$ year & 85 \\
\hline E & 55 65 year & 106 \\
\hline
\end{tabular}




\begin{tabular}{|c|c|c|}
\hline $\mathrm{F}$ & $>65$ year & 23 \\
\hline \multicolumn{2}{|c|}{ Total } & 400 \\
\hline
\end{tabular}

Then presented in a circle diagram of the visualization results using software $\mathrm{R}$ which is presented in Table 4.6 for gender frequencies as follows:

\begin{tabular}{|c|c|c|}
\hline \multicolumn{3}{|c|}{ Table 4.6 } \\
\hline Frequency of Classification and Respondent Age Percentage \\
\hline Classification of age & Frequency (Respondent) & $\%$ \\
\hline Muda & 186 & 46,5 \\
\hline Dewasa & 214 & 53,5 \\
\hline Total & 400 & 100 \\
\hline
\end{tabular}

Sumber : Hasil Pengolahan Software Excell

\subsubsection{Characteristics of Respondent Education Classification}

This study classifies Primary and Secondary Education (PDM) with a classification notation of 0 (zero) and the S-1, S-2, and S-3 education strata are stated as higher education classifications with a notation of 1 (one). Based on the results of grouping the characteristics of the respondent's educational level through calculations using MS Excel software which initially consisted of 4 educational strata. Which is presented in Table 4.7 as follows:

\begin{tabular}{|c|c|}
\hline \multicolumn{2}{|c|}{ Table 4.7} \\
Frequency of Respondent Education Level \\
\hline Education Level & Frequency (Respondent) \\
\hline Elementary and High School & 52 \\
\hline S-1 (Sarjana) & 176 \\
\hline Education Level & Frequency (Respondent) \\
\hline S-1 (Sarjana) & 176 \\
\hline S-2 (Magister) & 20 \\
\hline S-3 (PhD) & 400 \\
\hline total & \\
\hline
\end{tabular}

From Table 3.7, it can be identified that the majority of respondents have a bachelor's degree (S-1) as many as 176 people, while the least number of respondents has a doctoral degree as many as 20 people.

Furthermore, it is presented in a circle diagram of the visualization results using $\mathrm{R}$ software which is presented in Table 4.8 for gender frequencies as follows:

Table 4.8

Frequency of Classification and dan Respondent Education Percentage 


\begin{tabular}{|c|c|c|}
\hline Classification of Education Respondent & Frequency (Respondent & $\%$ \\
\hline Not Higher Education & 52 & 13 \\
\hline Higher Education & 348 & 87 \\
\hline Total & 400 & 100 \\
\hline
\end{tabular}

Sumber : Hasil Pengolahan Software Excell

\subsubsection{Characteristics of Respondents' Classification of Income}

This study classifies based on a reference to the average or average income of respondents, provided that respondents who have income below the average value are classified as lowincome income above Rp. 5,000,000 with a notation of 0 (zero) and those who have a high income are classified as high income, income above Rp. 5,000,000 with 1 (one) notation. Based on the results of grouping the characteristics of the respondent's income through calculations using MS Excel software which consists of seven income levels, presented in Table 4.9 as follows.

\begin{tabular}{|c|c|c|}
\hline \multicolumn{3}{|c|}{ Table 4.9} \\
\hline & Frequency of Classification Respondent Income \\
\hline Classification of Income & Frequency (Respondent) \\
\hline B & Rp.5.000.000,- - Rp.10.000.000,- & 110 \\
\hline C & Rp.10.000.000,- - Rp.15.000.000,- & 124 \\
\hline D & Rp.15.000.000,- - Rp.20.000.000,- & 43 \\
\hline E & Rp.20.000.000,- - Rp.25.000.000,- & 30 \\
\hline F & Rp.25.000.000,- - Rp.30.000.000,- & 24 \\
\hline G & $>$ Rp.30.000.000,- & 18 \\
\hline \multicolumn{2}{|c|}{ Total } & 51 \\
\hline
\end{tabular}

From Table 4.9 it can be identified the income of respondent A as many as 110 people, B as many as 124 people, $\mathrm{C}$ as many as 43 people, D as many as 30 people, E as many as 24 people, $\mathrm{F}$ as many as 18 people and $\mathrm{G}$ as many as 51 people. Then visually presented in a pie chart expressed in percentage units on

Based on the results of grouping the characteristics of respondents' income levels through calculations using MS Excel software, it consists of seven income levels. Furthermore, to meet the suitability of the data measurement scale required by the SEM-PLS model into the nominal two classifications, the income levels of the respondents above were transformed into two income classifications less than or equal to IDR 5,000,000 and greater than IDR 5,000. 000, -, classification of income, work results (business and so on), using a standard income of less or equal to Rp. 5,000,000 according to the DKI Jakarta Regional Minimum Wage (UMR) standard of Rp. 4,920,000, - which is rounded up to IDR 5,000,000. The results obtained for respondents were less than or equal to IDR 5,000,000 as many as 110 people and greater than IDR 5,000,000 as many as 290 people. Furthermore, it is presented in a circle diagram of the visualization results using $\mathrm{R}$ software which is presented in Table 4.10 for gender frequencies as follows: 


\begin{tabular}{|c|c|c|}
\hline \multicolumn{3}{|c|}{ Tabel 4.10 } \\
\hline Frequency of Classification Respondent Income \\
\hline Level of Income & Frequency (Respondent) & $\%$ \\
\hline$\leq$ Rp.5.000.000,- & 110 & 27,5 \\
\hline$>$ Rp.5.000.000,- & 290 & 72,75 \\
\hline Total & 400 & 100 \\
\hline
\end{tabular}

Sumber: Hasil Pengolahan Software Excell

From Table 4.10 it can be identified that the majority of respondents with an income level of above Rp. 5,000,000 are 290 people, as many as 110 people have an income level of less or equal to Rp. 5,000,000.

\subsubsection{Characteristics of Respondents' Religious Classification}

Based on the results of grouping the religious characteristics of respondents through calculations using MS Excel software, it was found that 398 respondents were Muslim, 1 person was Christian and the other was 1 person. Subsequently presented in the circle diagram the results of the visualization using software $\mathrm{R}$ are presented in Table 4.11 for the frequency of religion as follows:

\begin{tabular}{|c|c|}
\hline \multicolumn{2}{|c|}{ Tabel 4.11 } \\
Frequency of Classification Respondent Religion \\
\hline Religion & Frequency (Respondent) \\
\hline Islam & 398 \\
\hline Kristen & 1 \\
\hline Other & 1 \\
\hline Total & 400 \\
\hline
\end{tabular}

From table 4.11 the religious classification of respondents can be identified that the majority of respondents are Muslim, as many as 398 people, the remaining 2 are Christian and others. Whereas the classification of Religion which is expressed in percentage units is presented in Figure 3.8. The Characteristics of Religion of the following respondents which describe the percentage and number of followers of Islam and non-Islamic religions, the presentation is only shown by respondents who follow Islam in the percentage of $99.995 \%$ or 398 respondents, which is in line with the fact that the population of Indonesia is Muslim or Muslim.

\subsubsection{Characteristics of Respondent Residence Classification}

Based on the results of grouping the characteristics of the respondent's residence through calculations using MS Excel software, it was obtained that respondents with residences in Jabodetabek namely Jakarta, Bogor, Depok, Tangerang, and Bekasi were 293 people each Jakarta were 111 people, Bogor was 22 people, Depok was 25 people, Tangerang as many as 
31 people and Bekasi as many as 104 people, outside Jabodetabek as many as 107 people consisting of the Special Region of Yogyakarta as many as 24 people, West Java as many as 10 people, Central Java as many as 21 people, East Java as many as 15 people, Kalimantan as many as 7 people, Sumatra as many as 10 people and others as many as 9 people. Furthermore, it is presented in the circle diagram of the visualization results using $\mathrm{R}$ software which is presented in Table 4.12 for the frequency of residence as follows:

\begin{tabular}{|c|c|}
\hline \multicolumn{2}{|c|}{ Tabel 4.12 } \\
\hline Frequency of Classification of home Respondent \\
\hline Classification of Home Respondent & Frequency (Respondent) \\
\hline Jakarta & 111 \\
\hline Bogor & 22 \\
\hline Depok & 25 \\
\hline Tangerang & 31 \\
\hline Classification of Home Respondent & Frequency (Respondent) \\
\hline Bekasi & 104 \\
\hline Banten & 11 \\
\hline Daerah Istimewa Yogyakarta & 24 \\
\hline Jawa Barat & 10 \\
\hline Jawa Tengah & 21 \\
\hline Jawa Timur & 15 \\
\hline Kalimantan & 7 \\
\hline Sumatra & 10 \\
\hline Lainnya & 9 \\
\hline Total & 400 \\
\hline
\end{tabular}

From table 4.12 it can be identified the classification of respondents residing throughout Indonesia with the majority in Jakarta with 111 people and the lowest in other areas 2 people. Thus it can be identified that the majority of respondents live in Jakarta.

Based on the results of grouping the characteristics of the respondent's residence through calculations using MS Excel software, it was found that respondents with residences in Jabodetabek namely Jakarta, Bogor, Depok, Tangerang and Bekasi and outside Jabodetabek. Furthermore, it is presented in the circle diagram of the visualization results using $\mathrm{R}$ software which is presented in Table 4.13 for the frequency of residence as follows:

\begin{tabular}{|c|c|}
\hline \multicolumn{2}{|c|}{$\begin{array}{c}\text { Tabel } 4.13 \\
\text { Frequency of Classification of home Respondent Based } \\
\text { on Cluster }\end{array}$} \\
\hline Classification of Home Respondent & $\begin{array}{c}\text { Frequency } \\
\text { (Respondent) }\end{array}$ \\
\hline Jabodetabek & 293 \\
\hline Non-Jabodetabek & 107 \\
\hline Total & 400 \\
\hline
\end{tabular}


From table 4.13 it can be identified the classification of respondents residing throughout Indonesia with the majority in Jabodetabek with 293 people and the lowest in areas other than Jabodetabek 107 people.

\subsubsection{Characteristics of Respondent Bank Account Classification}

Based on the grouping of respondent bank characteristics using MS Excel software, it was found that the respondent banks were as many as Sharia Banks, Conventional Banks, and Sharia \& Conventional Banks, respectively 107, 221, and 72 people. Furthermore, it is presented in a circle diagram of the visualization results using $\mathrm{R}$ software which is presented in Table 4.14 for bank frequencies as follows:

\begin{tabular}{|c|c|}
\hline \multicolumn{2}{|c|}{ Tabel 4.14 } \\
Frequency of Classification of Respondent Bank \\
\hline Bank & Frequency (Respondent) \\
\hline Shariah Bank & 107 \\
\hline Conventional Bank & 221 \\
\hline Shariah and Conventional Bank & 42 \\
\hline Total & 400 \\
\hline
\end{tabular}

From Table 4.14 it can be identified that the classification of the majority of respondents has an account at a conventional bank followed by a sharia bank. Sharia and Conventional Banks as many as 221 people, 107 people, and 72 people, respectively.

\subsubsection{Characteristics of Respondent Status Classification}

Based on the results of grouping the characteristics of the respondent's status through calculations using MS Excel software, it consists of three statuses which are presented in Table 4:15 as follows:

\begin{tabular}{|c|c|}
\hline \multicolumn{2}{|c|}{ Tabel 4.15 } \\
Frequency of Classification of Respondent Status \\
\hline Status & Frequency (Respondent) \\
\hline Married & 333 \\
\hline Single & 56 \\
\hline Widower/widow & 11 \\
\hline Total & 400 \\
\hline
\end{tabular}

From Table 4.15 it can be identified that the majority of respondents are married as many as 333 people, 56 people are not yet married, while the least number of respondents who are widows/widows is 11 people.

\subsubsection{Characteristics of Respondents' Job Classification}


Based on the results of grouping the characteristics of the respondent's job through calculations using MS Excel software, it initially consists of three statuses which are presented in Table 4.16 as follows:

\begin{tabular}{|c|c|}
\hline \multicolumn{2}{|c|}{ Tabel 4.16} \\
\hline Frequency of Classification & of Respondent of Job \\
\hline Job & Frekuensi (Orang) \\
\hline Labor & 8 \\
\hline Professional & 196 \\
\hline Entrepreneur & 26 \\
\hline Job & 72 \\
\hline civil servants /TNI/POLRI & 74 \\
\hline Retirees & 24 \\
\hline Other & 400 \\
\hline Total & Frekuensi (Orang) \\
\hline
\end{tabular}

From Table 4.16 it can be identified that the majority of respondents for the job classification are 400 people, 8 laborers, 196 private/professional employees, 26 employers, 72 civil servants / TNI / Polri, 74 retirees, and 24 others.

\subsection{Validity Test of Questionnaire Statement Items}

Based on the results of testing the validity of each item of the questionnaire statement using the SPSS version of the software. 23, it is known that all statement items are valid. This is evidenced by the value of the correlation coefficient of the calculation results between each item of a statement with the total score using the Pearson formula written $r$ count as many as 57 items from 58 statement items greater than the critical value of table for the significance level (alpha $=\alpha$ ) of 0.07 with a value of 0.298 . namely the level of significance for the twotailed (2-Tailed) test. Meanwhile, one item of statement number 54, the value of $\mathrm{r}$ Count of 0.144296 is smaller than that of the table. Thus it can be said, by excluding statement item number 54 from the questionnaire instrument, out of the 57 statement items divided into the variables of religiosity and Islamic financial literacy were valid and appropriate or legally used for this study.

The results of the validity test for the variable Islamic financial literacy are 46 statement items, namely from the statement item numbers 13 to 58 . Through calculations with the help of SPSS version 20 software, one item number 54 is invalid and 45 statements are valid, so that the total statement items From the questionnaire for the two research variables of religiosity and Islamic financial literacy as many as 57 were declared valid, can legally be used as the basis for collecting research data.

\subsection{Reliability Test Results of the Financial Religiosity and Literacy Questionnaire}

Testing the reliability of the questionnaire instrument for the two research variables of religiosity and Islamic financial literacy using the help of SPSS software, the results are presented in Table 4.3 as follows: 


\begin{tabular}{|c|c|}
\hline $\begin{array}{r}\text { Result of Reliability } \\
\text { and }\end{array}$ & $\begin{array}{l}\text { bel. } 4.3 \\
\text { t for Questionnaire Religiosity } \\
\text { ncial Literacy }\end{array}$ \\
\hline Cronbach's Alpha & $\begin{array}{c}\text { Number of Questionnaire } \\
\text { Statement }\end{array}$ \\
\hline 0,930 & 57 \\
\hline
\end{tabular}

From Table 4.3, it can be identified that the reliability value of the research questionnaire instrument using the Crombach's Alpha measure is obtained at 0.930, it can be concluded that the research questionnaire instrument of religiosity and Islamic financial literacy is included in the very reliable category.

\subsection{Description of Endogenous Variables of Islamic Financial Literacy (X3)}

Of the 46 statement items related to the Islamic financial literacy variable, it is distributed into six manifest variables as follows:

\subsubsection{Knowledge Manifest Characteristics of Products and Services}

Based on the nine statement items as the manifestation of knowledge of the characteristics of Islamic financial products and services as indicators of endogenous variables of Islamic financial literacy, it can also be recapitulated and tabulated by the frequency distribution of the choice of attitudes of the respondents 'answers. Respondents' answers indicate the choice of the attitude of respondents on the manifest knowledge of partial products and services big agree.

\subsubsection{Community numeracy skills}

Based on the 10 statement items or items as the manifestation of the people's numeracy ability and also indicators of endogenous variables of Islamic financial literacy, it can be recapitulated and tabulated by the distribution pattern of the frequency of choice of respondent's response, the respondent's answer shows the choice of the attitude of the respondent on the manifest of community numeracy, most of whom agree.

\subsubsection{Attitude and Behavior Manifest}

Based on the 10 statement items or items as the manifestation of people's attitudes and behavior as well as indicators of endogenous variables of shari'ah financial literacy, it can be recapitulated and tabulated by the frequency distribution of respondents' attitude choices. Based on ten respondents' answers, it can be concluded that the choice of the attitude of the respondents on the manifestation of attitudes and behavior of the Indonesian people mostly agreed.

\subsubsection{Delivery Channel Manifest by Sector}

Based on the six statement items or items as the elaboration of the delivery channel manifest as well as indicators of endogenous variables Shari'ah Financial Literacy can be recapitulated and tabulated the frequency distribution of respondents' attitude choices, the 
result is that the respondent's answer is presented showing the choice of the attitude of the respondent on the manifest delivery channel per service sector for some big agree.

\subsubsection{Information Source Manifest}

Based on the six items of statements or items as the manifestation of information sources that affect decisions and indicators of endogenous shariah financial literacy variables, it can be recapitulated and tabulated by the frequency distribution of respondents 'attitude choices, indicating the choice of respondents' attitudes on the information source manifest for the majority of agreeing.

\subsubsection{Manifest Party Invited to Consult for Financial Advice}

Based on the six statement items or items as the manifestation of the frequency distribution of parties consulted for shari'ah financial advice as well as indicators of endogenous variables of shariah financial literacy, it can be recapitulated and tabulated as the frequency distribution of the respondent's choice of attitude, the result is the respondent's answer that is presented shows the respondent's attitude. on the manifest parties consulted with shariah financial advice for the most part agreed.

\subsubsection{Description of Intervening Variables Religiosity (X2)}

Of the 12 statement items relating to the religiosity variable, it is distributed into the five manifest variables as follows:

Manifest Tawheed. Based on the three statement items (items) as the elaboration of the manifest tauhid as an indicator of the mediating variable (intervening) religiosity, tawhid can be recapitulated and tabulated by the frequency distribution of the choice of attitudes from the respondents 'answers, indicating that the respondents' choice of tawhid manifest respondents strongly agreed.

Ritualistic Manifest. Based on the three statement items or items as the elaboration of the ritualistic manifest as an indicator of the intervening variable of religiosity, it can be recapitulated and tabulated that the frequency distribution of the choice of attitudes from the respondents 'answers, shows that the choice of respondents' attitudes on the ritual manifest most of them strongly agree.

Intellectual Manifest (Muamalah). Based on the three statement items or items as the elaboration of the intellectual manifest (muamalah) as an indicator of intervening religiosity variables, it can be recapitulated and tabulated by the frequency distribution of attitude choices from respondents 'answers, indicating the choice of respondents' attitudes on the intellectual manifest (muamalah), most of them strongly agree.

Manifest Consequences (Morals). Based on the two statement items (items as the manifestation of the consequence manifest as an indicator of the intervening variable of religiosity can be recapitulated and tabulated in the frequency distribution of the choice of attitudes of the respondents 'answers, it shows that the choice of respondents' attitudes on the intellectual manifest, most of them strongly agree. 
Experience Manifest. Based on the two statement items (items) as a description of the manifest experience (takwa) as an indicator of the intervening variable of religiosity, it can be recapitulated and tabulated by the frequency distribution of the choice of attitudes from the respondents 'answers, indicating that the choice of respondents' attitudes on the experience manifests mostly stated strongly agree.

\section{Conclusion}

The result of this research is Islamic financial literacy characteristics of product and service knowledge, counting skills, attitudes and behavior, delivery channel, resources, and reference reflected latent variable of Islamic financial literacy and demographic characteristics of gender, age, education, and income expenditure are reflected by a latent variable of demographic, and religiosity characteristics of monotheism, rituals, muamalah, morals, and experience are reflected by a latent variable of religiosity.

\subsection{Suggestions}

Accordingly, shariah bank industry could launch shariah products through women majelis taklim and, more socialization shariah product via religious preacher to grow shariah bank asset. and or another socialization way to campaign products and services of Islamic to customers.

Stakeholders in the Islamic banking industry can use the results of this study to be used in the global financial industry, especially Islamic financial institutions in developing business and marketing strategies, useful for policymakers, regulators, and banks that prioritize financial literacy and inclusion and financial education strategies according to the level developed by financial institutions. 


\section{References}

Abdullah, Dr Hjh Rose and Razak, Ahmad Lutfi Haji Abdul, "Exploratory Research into Islamic Financial Literacy in Brunei Darussalam", di akses tanggal 2 Mei 2020 dari https://www.researchgate.net/publication/283225608, DOI: 10.13140/RG.2.1.4815.1765

Alfa,Alodya Ann Gita, Rachmatin, Dewi dan Agustina,Fitriani, “Analisa Pengaruh Faktor Keputusan Konsumen Dengan Structural Equation Modelling Partial Least Square”, EurekaMatika, Vol. 5 , No . 2, 2017

al-Faizin, Abdul Wahid dan Akbar, Nashr,Tafsir Ekonomi Kontemporer (Menggali Teori Ekonomi dari Ayat Ayat Al Qur'an), ,(Depok:Gema Insani, 2018)

Allianz 2017 Report, "When will the penny drop? Money, financial literacy and risk in the digital age", di akses pada tanggal 2April 2019 dari https://gflec.org/initiatives/money-finlit-risk/

Anshori, Abdul Ghofur, Perbankan Syariah di Indonesia"(Yogyakarta: Gajah Mada University Press, 2018,e-book) diakses pada 10 November 2019 dari https://books.google.co.id/books?

Aziz, Shahab and Afaq, Zahra, "Adoption of Islamic banking in Pakistan an empirical investigation", Aziz \& Afaq, Cogent Business \& Management (2018), 5: 1548050 ,p.1-18, https://doi.org/10.1080/23311975.2018.1548050

Bank Indonesia, "Sejarah Perbankan Periode 1983-1997 - Bank Indonesia" diakses pada 7 Juli 2020 dari www.bi.go.id > museum > sejarah-bi >

BPS Propinsi Aceh, "Jumlah Penduduk Menurut Kabupaten/Kota dan Agama y ang Dianut di Propinsi Aceh, 2016" laporan diakses pada 12 Februari 2019 dari https://aceh.bps.go.id/quickMap.html

BPS Propinsi Jambi, "Jumlah Penduduk Menurut Kabupaten/Kota dan Jenis Kelamin y ang Dianut di Provinsi Jambi, 2016" laporan diakses pada 12 Februari 2019 dari https://jambi.bps.go.id/dy namictable/2018/05/16/444/penduduk-provinsi-jambi-menurutkabupaten-kota-dan-jenis-kelamin-tahun-2000-2017.html, https://www.kamusdata.com/daftarnama-kabupaten-dan-kota-provinsi-jambi/)

BPS Propinsi Jawa Tengah, "Jumlah Penduduk Menurut Kabupaten/Kota dan Jenis Kelamin di Provinsi Jawa Tengah, 2016" laporan diakses pada 12 Februari 2019 dari https://jateng.bps.go.id/dynamictable/2015/08/03/2/jumlah-penduduk-menurut-kabupaten-kotadan-jenis-kelamin-1993---2018.html

BPS Propinsi Jawa Timur, ’Jumlah Penduduk Menurut Kabupaten/Kota dan Agama yang Dianut di Provinsi Jawa Timur, 2016", laporan diakses pada 12 Februari 2019 dari https://jatim.bps.go.id/dy namictable/2017/10/09/120/jumlah-penduduk-menurut-kabup aten-kotadan-agama-y ang-dianut-di-provinsi-jawa-timur-2016.html

BPS Propinsi Maluku Utara, "Jumlah Penduduk dan Rasio Jenis Kelamin menurut Kabupaten/Kotadi Provinsi Maluku Utara, 2016” laporan diakses pada 12 Februari 2019 dari https://malut.bps.go.id/dy namictable/2015/09/22/70/jumlah-penduduk-dan-rasio-jenis-kelaminmenurut-kabupaten-kota-tahun-2010-2017.html, dan https://id.wikipedia.org/wiki/Maluku_Utara

BPS Propinsi Sumatera Barat, "Jumlah Penduduk Menurut Kelompok Umur dan Jenis Kelamin di Provinsi Sumatera Barat, 2016" laporan diakses pada 12 Februari 2019 dari https://sumbar.bps.go.id/dy namictable/2017/11/03/124/jumlah-penduduk-menurut-kelompokumur-dan-jenis-kelamin-2010-2016-jiwa-.html, dan https://id.wikipedia.org/wiki/Sumatera Barat

Choliq, H.Abdul dan Misbach, Irwan,"Perbandingan Kualitas Lay anan Bank Sy ariah dan Bank Konvensional”, Jurnal Keuangan dan Perbankan Vol.20, No.1 Januari 2016, hlm. 127-140

CIA World Factbook , (2016). “10 Negara dengan Jumlah Penduduk Populasi Terbany ak diDunia.”, diakses pada $21 \mathrm{Maret} 2019$ dari http://ilmupengetahuanumum.com/10-negara-den gan-ju mlahpenduduk-populasi-terbany ak-di-dunia/

CNN Indonesia, “Apakah Umat Islam Boleh Menabung di Bank Konvensional?” diakses pada 30 Juni 2020 dari https://www.cnnindonesia.com/gaya-hidup/20200427075420-289-497494/apakahumat-islam-boleh-menabung-di-bank-konvensional 
Connors, Gerard J., Tonigan, J. Scott and Miller, William R., "A Measure of Religious Background and Behavior for Use in Behavior Change Research", Psychology of Addictive Behaviors 1996, Vol. 10, No. 2, p.90-96

Davies, Peter, "Towards a framework for financial literacy in the context of democracy", Journal Curriculum Studies, 2015 Vol.47,No.2,h.300-316, http://dx.doi.org/10.1080/00220272.2014.934717

Delener, Nejdet, "Religious Contrast in Consumer Decision Behavior Patterns: Their Dimensions and Marketing Implications", European Journal of Marketing, Vol 28, No. 5 (1994): 36-53.

Dhimas, "May oritas Muslim, Ekonomi Islam Sulit Kuasai Perbankan Indonesia", diakses pada 30 Juni 2020 dari https://fin.co.id/2019/08/26/may oritas-muslim-ekonomi-islam-sulit-kuasai-perbankanindonesial

Ermawati, Nanik "Pengaruh Religiusitas, Kesadaran Wajib Pajak dan Pengetahuan Perpajakan Terhadap Kepatuhan Wajib Pajak", Jurnal STIE Semarang Vol.10 Issue 1 hal.106-122

Fam, K.S., Waller, D.S. and Erdogan, B.Z., "The influence of religion on attitudes towards the advertising of controversial products", European Journal of Marketing, Vol. 38 No. 5, 2002, pp. $537-55$

Fanny, Matius, "Structural Equation Modeling (SEM)", artikel diakses pada 2 Desember 2018 dari https://www.academia.edu/30428057/Structural Equation Modeling SEM

Fatwa Majelis Tarjih dan Tajdid Pimpinan Pusat Muhammadiy ah Nomor 08 tahun 2006.

Fatwa Majelis Ulama Indonesia Nomor 1 Tahun 2004 Tentang Bunga (Interest/faidah).

Gufron, M.Nur, \& Risnawati S, Teori-teori Psikologi, (Yogy akarta: Ar-Ruzz Media Group, 2010)

Hair, Joseph F. Jr. dkk., A Primer Partial Least Squares Structural Equation Modelling (PLS-SEM), (California : SAGE Publications Ltd., 2014)

Hakim, Muhammad Arief Rachman dan Hakim, Aminullah Achmad Muttaqin, "Analisa Pengaruh Literasi Keuangan Syariah Terhadap KeputusanMembuka Rekening Syariah (Studi Pada Mahasiswa Islam Kota Malang)", diakses pada 30 Juni 2020 dari jimfeb.ub.ac.id > index.php > jimfeb > article >

Handay ani, R, Darwini Sri, Eka Agustiani, Eka, Imanuella, "Pengaruh Religiusitas Terhadap Perilaku Memilih Bank Sy ariah Melalui Kepercay aan Merek (Studi Pada Nasabah Bank Sy ariah di Kota Mataram)”, Jurnal Ilmu Manajemen dan Bisnis, Vol. 6, No. 2 - September 2018 Halaman 47 s.d 59

Hawkins, D., J.; Coney, K., A. and Best, R. , Consumer Behaviour: Implications for Marketing Strategy, (Texas: Business Publications, 1980)

Hiday at, Bahril, "Pskilogi Agama, Bahan Ajar Program Studi Pendidikan Agama Islam Universitas Islam Riau, Agustus 2017" di akses tanggal 19 Juli 2019 dari https://www.researchgate.net/publication/320163143

Huston, Sandra J., "Measuring Financial Literacy", The Journal of Consumer Affairs, Vol. 44, No. 2, 2010 p. $296-316$

Ireland, J.J. (2018), "Just how loyal are Islamic banking customers?", International Journal of Bank Marketing, Vol. 36 No. 3, pp.410-422.https://doi.org/10.1108/IJBM-09-2016-0138

Jahja, Adi Susilo Jahja, “Konsep, Dimensi, Variable, Indikator dan Pengukuran”, artikel diakses pada 12 Desember 2018 dari, https://dosen.perbanas.id/konsep-dimensi-variable-indikator-pengukuran.

Jalaludin, Psikologi Agama, (Jakarta : Grafindo Persada, 2007)

Jayani, Dwi Hadya, "Berapa Asset Bank Syariah dan Konvensional ?" diakses pada 2 Juni 2020 dari https:/0/databoks.katadata.co.id/datapublish/2019/09/20/berapa-aset-perbankan-sy ariah-dankonvensional\#

Johan, Zaimy Johana and Putit, Lennora, "Conceptualizing the Influences of Knowledge and Religiosity on Islamic Credit Card Compliance", Procedia Economics and Finance 37 ( 2016 ) 480 - 487

Krauss, S. E., Hamzah, A., dan Idris, F. 2007. "Adaptation of Muslim Religiosity Scale for Use with Four Different Faith Commnunities in Malay sia". Review of Religious Research, Vol.49 No.2: $147-164$ 
Kumedi Ja'far, A. "Peranan Hukum Islam Dalam Pembangunan Ekonomi Di Indonesia", artikel diakses 3 Februari 2019 dari https://media.neliti.com/media/publications/177841-ID-perananhukum-islam-dalam-pembangunan-ek.pdf

Kusumadewi, Rita, Yusuf, H. Ayus Ahmad, dan Wartoyo, Literasi Keuangan Sy ariah di Kalangan Pondok Pesantren (CV.Elsi Pro: Cirebon, 2019, e-book)

Kusumadewi, Rita, Yusuf, H. Ayus Ahmad, dan Wartoyo, Literasi Keuangan Sy ariah di Kalangan Pondok Pesantren (CV.Elsi Pro: Cirebon, 2019, e-book)

Lokadata, "Populasi Penduduk DKI Jakarta berdasarkan agama", laporan di akses tanggal 12 Februari 2019 dari https://lokadata.beritagar.id/chart/preview/populasi-penduduk-dki-jakarta-berdasarkanagama-1520252043

Lusardi, Annamaria and Mitchell, Olivia S "Financial literacy and retirement planning in the United States", Journal of Pension Economics and Finance, 10(4), 2011, h.509-525.

Lusardi, Annamaria and Mitchell, Olivia S "Financial literacy and retirement planning in the United States", Journal of Pension Economics and Finance, 10(4), 2011, h.509-525.

Lusardi, Annamaria and Mitchell, Olivia S., "The Economic Importance of Financial Literacy: Theory and Evidence", Journal Of Economic Literature Vol. 52, No. 1, 2014, p. 5-44

Lusardi, Annamaria and Mitchell, Olivia S., "The Economic Importance of Financial Literacy: Theory and Evidence", Journal Of Economic Literature Vol. 52, No. 1, 2014, p. 5-44

Lusardi, Annamaria and Mitchell, Olivia S., "Financial literacy around the world: an overview," Journal of pension economics \& finance, 10(4), 497- 508.

Masykuroh, Ely, "Penduduk Muslim Sebagai Potensi Pasar Perbankan Sy ariah (Studi Komparasi Kekuatan Pasar Perbankan di Indonesia)", Kodifikasia Volume 11 No. 1 Tahun 2017 p.131-155

Morissan M. A, dkk, Metode Penelitian Survei, (Jakarta: Kencana, 2012)

Muhamad dan Triwulandari, Andriy ani "Pengaruh Modal Sosial, Kearifan Lokal, Religiusitas dan factor Ekonomi terhadap Kepatuhan Syariah para Nasabah Pembiayaan BPRS di Yogyakarta," Equilibrium, Vol 3 No. 2 Juni (2016): 290-310.

Nasution, Harun, Islam Ditinjau Dari Berbagai Aspeknya, (Jakarta: Penerbitan Universitas Indonesia,1985)

Obeid, Hassan, "Empirical Investigation Into Customer Adoption Of Islamic Banking Services In Tunisia, The Journal of Applied Business Research - July/August 2016 Volume 32, Number 4 (2016): 1243-1256

Otoritas Jasa Keuangan, “Indonesian National Strategy For financial Literacy”, laporan diakses pada 4 Februari 2019 dari https://sikapiuangmu.ojk.go.id/FrontEnd/images/FileDownload/184_OJK_NATIONAL\%20STR ATEGY\%20FOR\%20FINANCIAL\%20LITERACY.pdf

Otoritas Jasa Keuangan, "Survei Nasional Literasi dan Inklusi Keuangan Indonesia 2016”, laporan diakses pada 12 Desember 2018 dari https://sikapiuangmu.ojk.go.id/frontend/cms/detailmateri/250

Rehman, Ateeq-ur and Shabbir, Muhammad Shahbaz, "The relationship between religiosity and new product adoption", Journal of Islamic Marketing, Vol. 1 Iss: 1,2010, pp. 63 - 69

Risfandy, Tastaftiy an, Husa, Putri Permatasari and Asrihap sari, Andi, "Day a Saing Bank Sy ariah di Sebuah Negara Religius: Temuan Empirik dari Indonesia", Jurnal Keuangan dan Perbankan Vol. 20, No.2, Mei 2016: 282-291

Rosyidah, Siti Mar'atur and Lestari,Wiwik , "Religiusitas dan Persepsi Risiko Dalam Pengambilan Keputusan Investasi Pada Perspektif Gender", Journal of Business and Banking Volume 3, No. 2 , November 2013, pages $189-200$

Rusydiana, Aam Slamet and Hasib, Fatin Fadhilah, "Islamic Banking Selection Criteria: Case in Indonesia Using Analytic Network Process”, Economica: Jurnal Ekonomi Islam -Volume 10, Nomor 1 (2019): 165 - 188 DOI: https://dx.doi.org/10.21580/economica.2019.10.1.2846

Sawitri, Ni Ny oman and Febrian, Erie, "Determinants Of Demand For Islamic Banking Services: A Survey On Moslem Public Servants In Indonesia", Malaysian Journal of Consumer and Family Economics (2018) Vol 21 (Secial Issue 2)

Schumaker, J.F., (Ed.), Religion and mental health. (New York: Oxford University Press, 1992) 
Souiden, N. and Rani, M. (2015), "Consumer attitudes and purchase intentions toward Islamic banks: the influence of religiosity", International Journal of Bank Marketing, Vol. 33 No. 2, pp. 143-161. https://doi.org/10.1108/IJBM-10-2013-0115

Sugiy ono, Metode Penelitian Kuantitatif Kualitatif dan $R \& D$, (Bandung:Alfabeta, 2009)

Sugiy ono, Metode Penelitian Kuantitatif Kualitatif dan R\&D, (Bandung:Alfabeta, 2009)

Susanti, Elvi, Glosarium Kosakata Bahasa Indonesia Dalam Ragam Media Sosial, Dialekta jurnal bahasa, sastra, dan pendidikan bahasa dan sastra Indonesia, 3(2), 2016, 229-250, Permalink/DOI: http://dx.doi.org/10.15408/dialektika.v3i2.5188

Tambun, Sihar, "Workshop Metode Penelitian Kuantitatif, Metode Structural Modelling dan Interpretasi Hasil Penelitian Dengan Menggunakan Program Smart PLS (Partial Least Square)", workshop Jum'at 20 Juni 2014 (Universitas 17 Agustus 1945 Jakarta) h.1-21

Tiliouine, Habib \& Belgoumidi, Abbes," An Exploratory Study of Religiosity, Meaning in Life and Subjective Wellbeing in Muslim Students from Algeria", Applied Research Quality Life (2009) 4:109-127 